\title{
CARBOXYLIC ACID AMIDE (CAA) FUNGICIDE RESISTANCE PREVENTION STRATEGY
}

\author{
M.S. MOORE ${ }^{1}$, G.B. FOLLAS ${ }^{2}$, G.C. HAGERTY ${ }^{3}$ and \\ R.M. BERESFORD ${ }^{4}$
}

\begin{abstract}
${ }^{1}$ Bayer CropScience, 91 Treffers Road, Sockburn, Christchurch, New Zealand
${ }^{2}$ Syngenta Crop Protection Ltd., Tower 2, Level 7, 110 Symonds St, Auckland, New Zealand

${ }^{3}$ BASF New Zealand Ltd, 1/333 Harewood Rd, Christchurch, New Zealand

${ }^{4}$ The Horticulture and Food Research Institute of New Zealand Ltd, Mt Albert Research Centre, Private Bag 92169, Auckland, New Zealand
\end{abstract}

Corresponding author: rberesford@hortresearch.co.nz

\begin{abstract}
CAA fungicides are currently represented in New Zealand by the three active ingredients, dimethomorph, iprovalicarb and mandipropamid. They are currently registered in New Zealand for use against oomycete fungi in grapes, onions, potatoes and lettuce. These fungicides are considered to have low to medium risk of resistance development and resistance management is recommended by the Fungicide Resistance Action Committee (FRAC) in Europe. Guidelines are presented for fungicide use that will avoid or delay the development of resistance to CAA fungicides. Keywords: fungicide resistance prevention, Plasmopara viticola, Bremia lactucae, Peronospora destructor, Phytophthora infestans.
\end{abstract}

\section{INTRODUCTION}

These guidelines are designed to avoid or delay the development of resistance to carboxylic acid amide (CAA) fungicides, which are currently represented in New Zealand by the three active ingredients, dimethomorph, iprovalicarb and mandipropamid. The CAA group was proposed in 2007 by the Fungicide Resistance Action Committee (FRAC) in Europe under their code group No. 40 (www.frac.info/frac/index.htm) and includes compounds from the three different chemical groups, cinnamic acid amides (dimethomorph), valinamide carbamates (iprovalicarb) and mandelic acid amides (mandipropamid). This strategy incorporates the strategy for dimethomorph, which was previously listed separately in New Zealand (Beresford 2005, Beresford et al. 1996). These guidelines have been developed in consultation with the New Zealand Association for Animal Health and Crop Protection (AGCARM, www.agcarm.co.nz/) and are based on recommendations from FRAC. All New Zealand pesticide resistance strategies can be found on the New Zealand Plant Protection Society web site (www.nzpps.org).

\section{PRODUCT PERSPECTIVE}

Carboxylic acid amide derivates have been available internationally since the late 1980s and in New Zealand are currently available as dimethomorph, in Acrobat ${ }^{\circledR}$ MZ690 registered in 1994; iprovalicarb, in Melody Duo® registered in 2006; and mandipropamid, in Revus ${ }^{\circledR}$ registered in 2007. CAA fungicides exhibit translaminar movement in the plant and although their mode of action is not certain, it is proposed that they inhibit phospholipid biosynthesis and interfere with cell wall deposition. They are considered to have low to medium risk of resistance development and resistance management is required. 
TABLE 1: Pathogens and crops targeted by carboxylic acid amides in New Zealand.

\begin{tabular}{lcc}
\hline Pathogen & Disease & Crop \\
\hline Plasmopara viticola & Downy mildew & Grape \\
Bremia lactucae & Downy mildew & Lettuce \\
Peronospora destructor & Downy mildew & Onion \\
Phytophthora infestans & Late blight & Potato \\
\hline
\end{tabular}

\section{CURRENT STATUS OF CARBOXYLIC ACID AMIDE (CAA) RESISTANCE}

Dimethomorph, which causes cell wall lysis in oomycete fungi (Albert et al. 1988), has shown no cross-resistance to phenylamide fungicides (Jensen \& Lundsgaard 1999). Mutants of Phytophthora capsici moderately resistant to dimethomorph were induced in the laboratory with chemical mutagenesis, but not through adaptation (Young et al. 2001). A small proportion of field isolates of $P$. infestans were found to be tolerant to dimethomorph in Russia, but resistant strains that were induced through repeated treatment of potato plots appeared to have reduced fitness (Dereviagina et al. 1999). Attempts to detect resistant strains in field populations of P. viticola in Germany were unsuccessful, as were attempts to induce resistant strains artificially (Bissbort \& Schlosser 1991).

The FRAC website (www.frac.info/frac/index.htm) has reported that sensitivity monitoring studies over several years revealed that in the populations of the potato late blight pathogen, Phytophthora infestans, all isolates were fully sensitive to CAA fungicides (Cohen et al. 2007). However, in populations of the grape downy mildew pathogen, Plasmopara viticola, isolates can be found in certain regions that are simultaneously resistant to all CAA fungicides. Therefore, in the case of Plasmopara viticola, a positive cross resistance among all CAA fungicides is obvious for the vast majority of isolates. The degree of sensitivity covers a wide range of EC50 values, with isolates being sensitive, moderately resistant and fully resistant (www.frac.info/frac/ index.htm).

Inheritance studies (Gisi et al. 2007) have shown that sexual crosses between sensitive and CAA-resistant isolates of $P$. viticola lead to a co-segregation of resistance to dimethomorph, iprovalicarb and mandipropamid, but not to the phenylamide mefenoxam, which was tested in parallel as an independent marker. Further, the inheritance studies showed that the gene(s) for resistance to CAA fungicides are inherited in a recessive manner. Therefore, the entire F1 generation of crosses between sensitive and CAAresistant isolates was sensitive, and only in the F2 progeny did CAA resistance reappear in a few isolates. These results suggest that the resistance risk can be classified as moderate (compared with high for phenylamide and Qol fungicides) and that it can be managed by appropriate use strategies, as proposed here.

\section{RESISTANCE PREVENTION STRATEGY}

Observe manufacturer's recommendations for application rate and timing. Exceeding the maximum number of applications per season could increase the risk of resistance development. Apply preventatively when disease levels are low, but there is a risk of infection. Weather-based disease forecasting criteria are available to help effective timing of fungicides for onion downy mildew and potato late blight.

\section{Grapes}

Apply a maximum of four applications per season. Apply CAA fungicides always in mixture with an effective fungicide that has an alternative mode of action. 


\section{Lettuce, onions and potatoes}

Follow the manufacturer's label directions. It is suggested that no more than $50 \%$ of the fungicide applications used against late blight or downy mildew should contain a CAA fungicide.

\section{Implementation recommendations}

Product labels should include a statement about resistance risk and a recommendation about the maximum numbers of carboxylic acid amide-containing fungicides that should be applied.

\section{REFERENCES}

Albert G, Curtze J, Drandarevski CA 1988. Dimethomorph (CME 151), a novel curative fungicide. Brighton Crop Protection Conference, Pests and Diseases 1: 17-24.

Beresford RM 2005. Dimethomorph management strategy. In: Martin NA, Beresford RM, Harrington KC ed. Pesticide resistance: prevention and management strategies 2005. New Zealand Plant Protection Society Inc., Hastings, New Zealand. Pp. 19-20.

Beresford R, Cromey M, Grbavac N, Smith B 1996. Morpholine resistance management strategy: In: Bourdot GW, Suckling DM ed. Pesticide resistance: prevention and management. New Zealand Plant Protection Society, Rotorua, New Zealand. Pp. 142-143.

Bissbort S, Schlosser E 1991. Sensitivity of Plasmopara viticola to dimethorph. Mededelingen Faculteit Landbouwwetenschappen, Rijksuniversiteit Gent, 56 (2b): 559-568.

Cohen Y, Rubin E, Hadad T, Gotlieb D, Sierotzki H, Gisi U 2007. Sensitivity of Phytophthora infestans to mandipropamid and the effect of enforced selection pressure in the field. Plant Pathology 56: 836-842.

Dereviagina MK, Elansky SN, Diakov YT 1999. Resistance of Phytophthora infestans to the dimethorph fungicide. Mikologiya Fitopatologiya 33 (3): 208-213.

Gisi U, Waldner M, Kraus N, Dubuis H, Sierotzki H. 2007. Inheritance of resistance to carboxylic acid amide (CAA) fungicides in Plasmopara viticola. Plant Pathology 56: 199-208.

Jensen CB, Lundsgaard J 1999. ACROBAT R WG - a new fungicide against downy mildew in onions and late blight in potatoes. $16^{\text {th }}$ Danish Plant Protection Conference. Crop protection in organic farming. Pests and diseases. DJF Rapport, Markbrug 10: 213-225.

Young DH, Spiewak SL, Slawecki RA 2001. Laboratory studies to assess the risk of development of resistance to zoxamide. Pest Management Science 57(11): 1081-1087. 